\title{
Optimization Of Natural Ventilation In Building As Passive Design Strategy For Health Security
}

\author{
Cynthia Permata Dewi \\ Department of Civil Engineering, State University of Malang, Malang, Indonesia \\ cynthia.dewi.ft@um.ac.id
}

\begin{abstract}
The use of natural ventilation strategy in a building is currently encouraged by the emergence of a pandemic Covid-19. In addition to its advantages in minimizing the use of electrical energy, the natural ventilation system is believed could reduce the possibility of spreading the virus. One design approach to this system is by using the window's design properly. Air movement inside a building should be utilized well to allow the movement from inlet to outlet. The position of the window was one of the variables examined in this study besides the types of the window. This study found that the use of a combination of $30^{\circ}$ awnings produced the highest airspeed in the living room $(R 1)$, while a combination of horizontal sliding windows resulted in the highest air velocity in the bedroom (R2). Still, the airspeed generated from the two combinations less than the minimum level of it is generally required, $0.75-0.9 \mathrm{~m} / \mathrm{s}$.
\end{abstract}

Keywords: Covid-19, natural ventilation, window's type, window's design, air movement

\section{Introduction}

The natural ventilation system is pointed on the process of supplying and removing the air inside the building by nature, on the other hand without using additional mechanical equipment. Several natural ventilation strategies can be used in building (Passivent Limited, 2015): 1.background ventilation which provides adequate indoor air quality throughout the year by using various façade's design, 2. Rapid ventilation system which is necessary to remove excess temperature, 3 . Cross ventilation system that used the air movement through inlet and outlet in two opposing façade, 4. Single-sided ventilation that used inlet and outlet on the same side of building façade, 5 . Passive stack ventilation uses a combination of cross ventilation, buoyancy and the suction effect as the wind passes the terminal, 6. Displacement ventilation uses wind-driven roof-mounted terminals with separated chambers to channel air down into the building regardless of wind direction, and the last is Night cooling uses the lower external temperatures at night to reduce the temperature of the building fabric, using automatic ventilation devices.

The principles of natural ventilation were divided into wind-driven ventilation and Buoyancy-Driven (Stack) Ventilation (Yang \& Clements-Croome, 2012). In wind-driven ventilation, the air movement is created by different pressures in the windward and leeward side of the building. While the stack ventilation, air movement inside the building is created by different temperatures. Moreover, to improve the speed of air velocity inside the building, the outlet should be bigger than the inlet (Lechner, 2007).

During the covid-19 period, the use of natural ventilation in a building is now encouraged by WHO (WHO, 2020). This strategy is proposed to be used to prevent the virus that causes COVID-19 from spreading indoors. WHO recommends in all workspaces, schools, and tourism accommodation to provide fresh and clean air. This goal can be achieved by using natural ventilation because natural ventilation did not recirculate the air inside the building.

In addition, the statement issued by WHO, there is also different research conducted in investigating the importance of using natural ventilation during this pandemic period. A study conducted by Bhagat in 2020 (Bhagat et al., 2020) found that the proper design of ventilation could encourage vertical stratification and remove warm air pollution near the ceiling, thus, could be effective in reducing the exposure risk. Another study also found that the use of natural ventilation could minimize the risk of spreading the virus (Bagdasarian et al., 2020) (Liedtke, 2020). 


\section{Experimental method}

This research was conducted in residential buildings. Using the virtual experimental method to examine airflow and velocity. The variables that use in this study are window type and position. CFD (Computational Fluid Dynamics) can

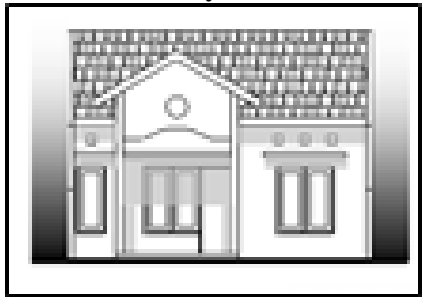

Figure 1 : The simulation model

\section{Simulation model}

The existing model refers to the actual condition without any modification. There is a previous field study that was conducted to get the various types of window that examine the air velocity inside the building whether its speed nor the direction (Guo et al., 2015). Moreover, the use of CFD as a simulation tool has its advantage in preprocessing, solving, and postprocessing (Cahyani, 2018).

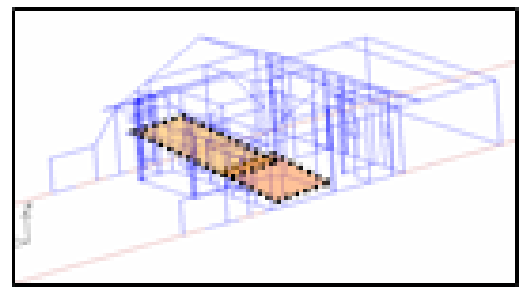

Table 1 Window's design alternatives

\begin{tabular}{|c|c|c|c|c|c|c|}
\hline \multirow{2}{*}{\multicolumn{2}{|c|}{ Alternative }} & \multicolumn{2}{|c|}{$\begin{array}{c}\text { Window's wide } \\
\text { (m) }\end{array}$} & \multicolumn{2}{|c|}{$\begin{array}{l}\text { Windonw's } \\
\text { position from } \\
\text { floor level (m) }\end{array}$} & \multirow[t]{2}{*}{ Window's type } \\
\hline & & R1 & R2 & $\mathrm{R} 1$ & R2 & \\
\hline \multirow{6}{*}{ A } & 1 & 0.6 & 0.5 & 0.35 & 0.55 & Awning \\
\hline & 2 & 0.6 & 0.5 & 0.4 & 0.85 & Awning \\
\hline & 3 & 0.6 & 0.5 & 0.5 & 1.5 & Awning \\
\hline & 4 & 0.6 & 0.5 & 0.35 & 0.55 & Jalousie \\
\hline & 5 & 0.6 & 0.5 & 0.4 & 0.85 & Jalousie \\
\hline & 6 & 0.6 & 0.5 & 0.5 & 1.5 & Jalousie \\
\hline \multirow{6}{*}{ B } & 1 & 0.6 & 0.6 & 0.35 & 0.55 & Awning \\
\hline & 2 & 0.6 & 0.6 & 0.4 & 0.85 & Awning \\
\hline & 3 & 0.6 & 0.6 & 0.5 & 1.5 & Awning \\
\hline & 4 & 0.6 & 0.6 & 0.35 & 0.55 & Jalousie \\
\hline & 5 & 0.6 & 0.6 & 0.4 & 0.85 & Jalousie \\
\hline & 6 & 0.6 & 0.6 & 0.5 & 1.5 & Jalousie \\
\hline \multirow{6}{*}{$\mathrm{C}$} & 1 & 0.6 & 0.8 & 0.35 & 0.55 & Awning \\
\hline & 2 & 0.6 & 0.8 & 0.4 & 0.85 & Awning \\
\hline & 3 & 0.6 & 0.8 & 0.5 & 1.5 & Awning \\
\hline & 4 & 0.6 & 0.8 & 0.35 & 0.55 & Jalousie \\
\hline & 5 & 0.6 & 0.8 & 0.4 & 0.85 & Jalousie \\
\hline & 6 & 0.6 & 0.8 & 0.5 & 1.5 & Jalousie \\
\hline \multirow{6}{*}{$\mathrm{D}$} & 1 & 0.7 & 0.5 & 0.35 & 0.55 & Awning \\
\hline & 2 & 0.7 & 0.5 & 0.4 & 0.85 & Awning \\
\hline & 3 & 0.7 & 0.5 & 0.5 & 1.5 & Awning \\
\hline & 4 & 0.7 & 0.5 & 0.35 & 0.55 & Jalousie \\
\hline & 5 & 0.7 & 0.5 & 0.4 & 0.85 & Jalousie \\
\hline & 6 & 0.7 & 0.5 & 0.5 & 1.5 & Jalousie \\
\hline \multirow{3}{*}{$\mathrm{E}$} & 1 & 0.7 & 0.6 & 0.35 & 0.55 & Awning \\
\hline & 2 & 0.7 & 0.6 & 0.4 & 0.85 & Awning \\
\hline & 3 & 0.7 & 0.6 & 0.5 & 1.5 & Awning \\
\hline
\end{tabular}




\begin{tabular}{|c|c|c|c|c|c|c|}
\hline & 4 & 0.7 & 0.6 & 0.35 & 0.55 & Jalousie \\
\hline & 5 & 0.7 & 0.6 & 0.4 & 0.85 & Jalousie \\
\hline & 6 & 0.7 & 0.6 & 0.5 & 1.5 & Jalousie \\
\hline \multirow{6}{*}{$\mathrm{F}$} & 1 & 0.7 & 0.8 & 0.35 & 0.55 & Awning \\
\hline & 2 & 0.7 & 0.8 & 0.4 & 0.85 & Awning \\
\hline & 3 & 0.7 & 0.8 & 0.5 & 1.5 & Awning \\
\hline & 4 & 0.7 & 0.8 & 0.35 & 0.55 & Jalousie \\
\hline & 5 & 0.7 & 0.8 & 0.4 & 0.85 & Jalousie \\
\hline & 6 & 0.7 & 0.8 & 0.5 & 1.5 & Jalousie \\
\hline \multirow{6}{*}{ G } & 1 & 0.8 & 0.5 & 0.35 & 0.55 & Awning \\
\hline & 2 & 0.8 & 0.5 & 0.4 & 0.85 & Awning \\
\hline & 3 & 0.8 & 0.5 & 0.5 & 1.5 & Awning \\
\hline & 4 & 0.8 & 0.5 & 0.35 & 0.55 & Jalousie \\
\hline & 5 & 0.8 & 0.5 & 0.4 & 0.85 & Jalousie \\
\hline & 6 & 0.8 & 0.5 & 0.5 & 1.5 & Jalousie \\
\hline \multirow{6}{*}{$\mathrm{H}$} & 1 & 0.8 & 0.6 & 0.35 & 0.55 & Awning \\
\hline & 2 & 0.8 & 0.6 & 0.4 & 0.85 & Awning \\
\hline & 3 & 0.8 & 0.6 & 0.5 & 1.5 & Awning \\
\hline & 4 & 0.8 & 0.6 & 0.35 & 0.55 & Jalousie \\
\hline & 5 & 0.8 & 0.6 & 0.4 & 0.85 & Jalousie \\
\hline & 6 & 0.8 & 0.6 & 0.5 & 1.5 & Jalousie \\
\hline \multirow{6}{*}{ I } & 1 & 0.8 & 0.8 & 0.35 & 0.55 & Awning \\
\hline & 2 & 0.8 & 0.8 & 0.4 & 0.85 & Awning \\
\hline & 3 & 0.8 & 0.8 & 0.5 & 1.5 & Awning \\
\hline & 4 & 0.8 & 0.8 & 0.35 & 0.55 & Jalousie \\
\hline & 5 & 0.8 & 0.8 & 0.4 & 0.85 & Jalousie \\
\hline & 6 & 0.8 & 0.8 & 0.5 & 1.5 & Jalousie \\
\hline
\end{tabular}
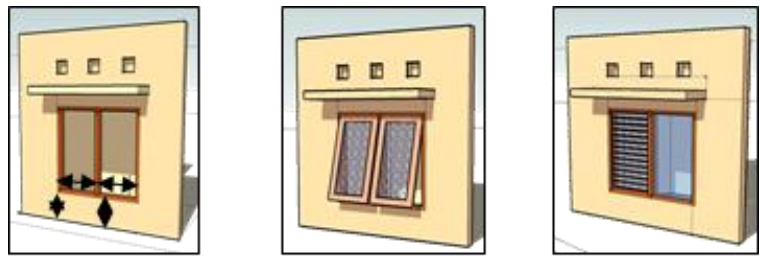

Figure 2: Window's type (awning and jalousie)

The observation was conducted in two rooms on a building. R1 was the guest room and $\mathrm{R} 2$ was the bedroom. The observation point was to take place $1.1 \mathrm{~m}$ from the floor level on the building (occupied zone). In each room, there were three observation points, in an inlet, in the middle point in the room, and the endpoint of the room.
The setting of the computational models was in steady-state condition based on the majority scenario on building simulation using CFD (Lishman \& Woods, 2006). Wind direction was set to ideal conditions that perpendicular to the windward side of a building. Local terrain was set to type 2 (urban, suburban, and wooded areas). 


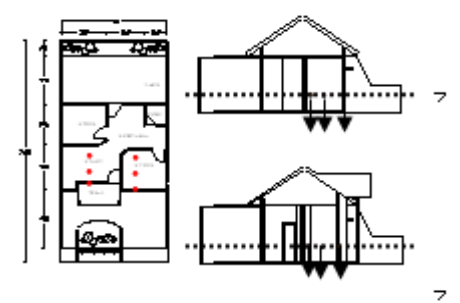

Figure 3: The investigation point in each room ( $R 1$ and $R 2)$

\section{Result and Discussion}

The existing model was simulated first.

The result shows that the air velocity in $\mathrm{R} 1$

was $0.07 \mathrm{~m} / \mathrm{s}$ and $0.11 \mathrm{~m} / \mathrm{s}$ in $\mathrm{R} 2$.

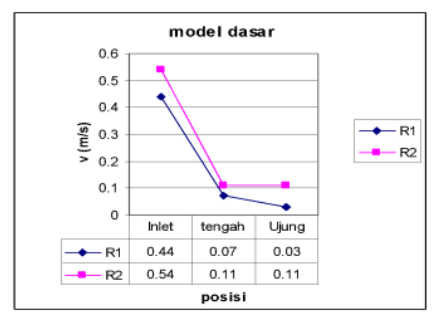

Figure 4: Simulation result for the existing model

Table 2: Simulation result for alternative models

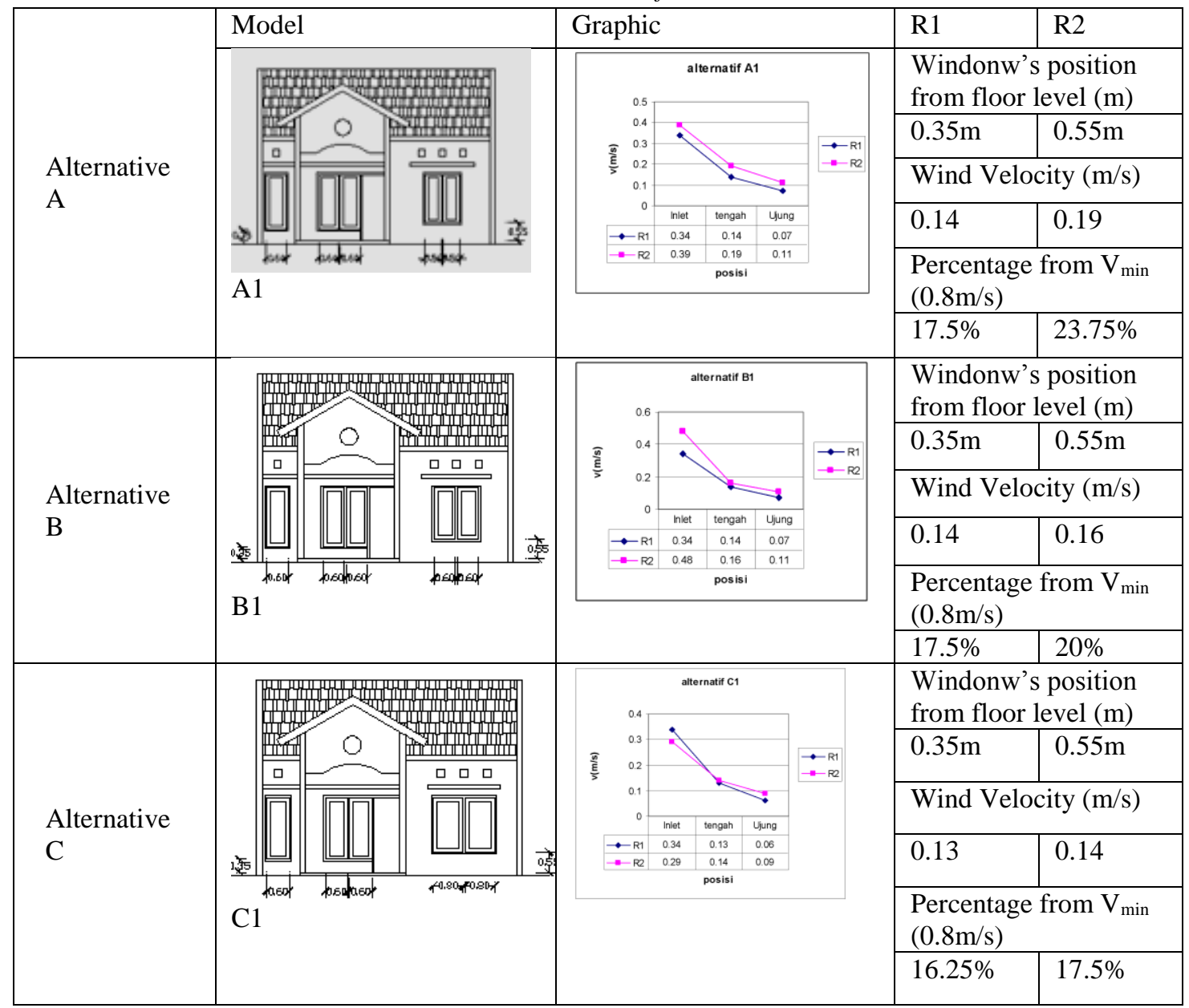


$1^{\text {st }}$ International Conference on Engineering (ICONE 2020) Architectural Support of Heritage. Culture, and Sustainable Development

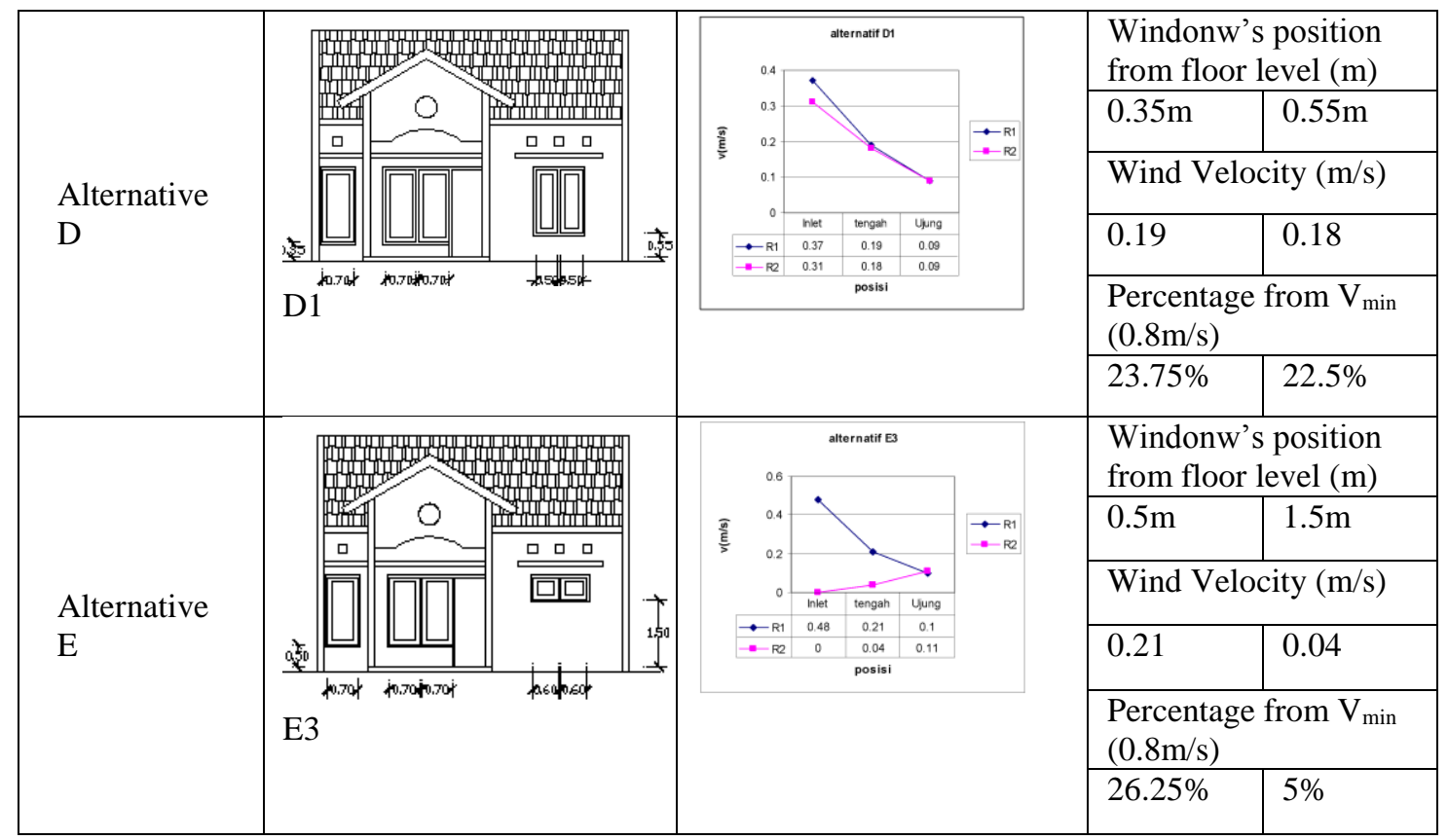

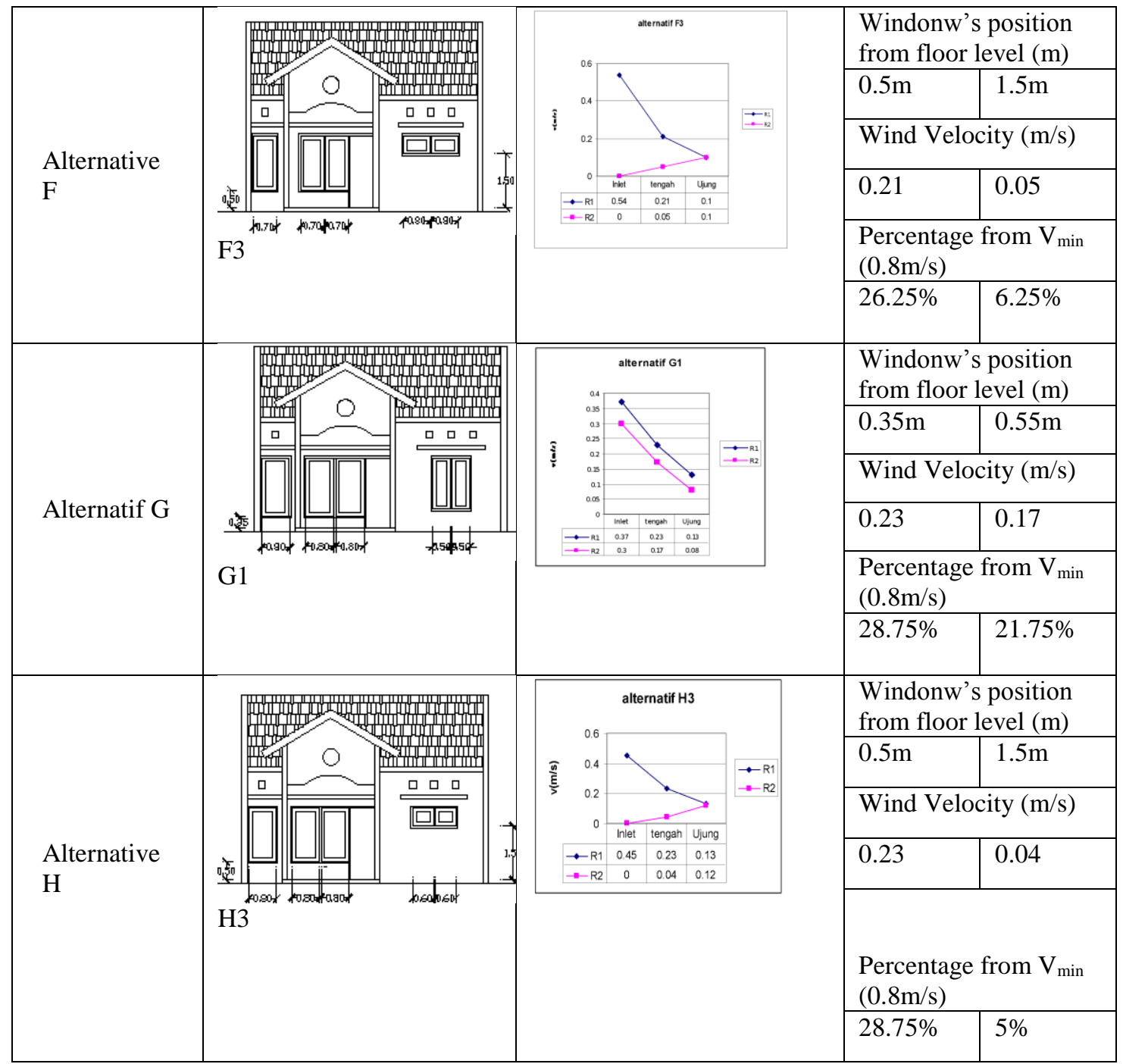

Faculty of Engineering Tunas Pembangunan Surakarta University 


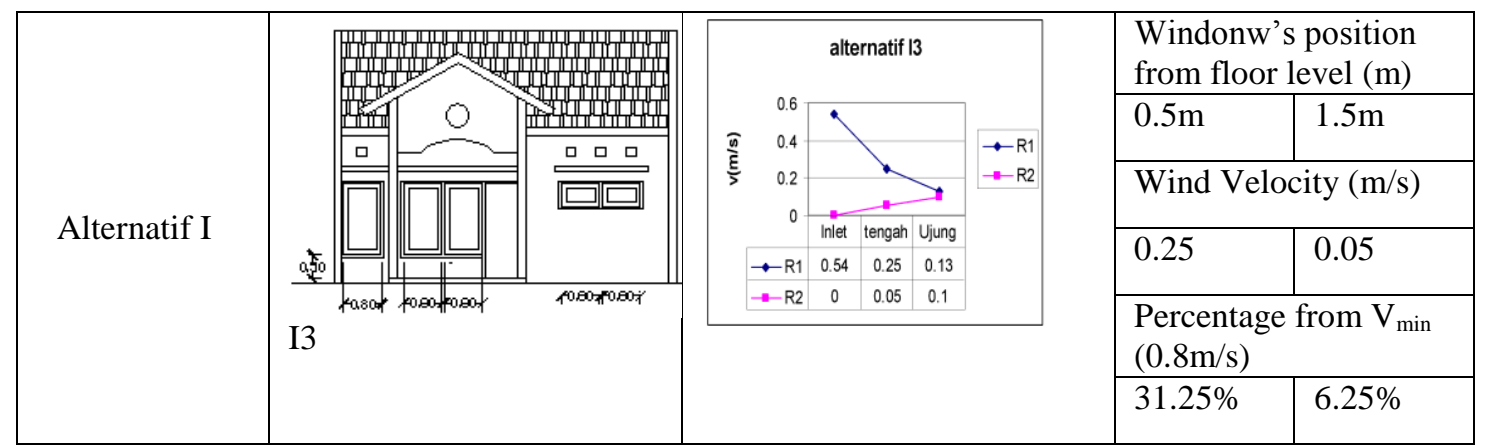

Based on the simulation result from alternative A to I, overall the result from the awning type was to create airflow upward. Thus, this type of window did not recommend a high position on the building façade because air movement flowed upward and couldn't pass the living zone. The air direction resulted in the same result as a previous study conducted by Kindangan (Kindangen, 2003). The result showed that the use of awning would guard the air movement into the

On the other hand, the use of a jalousie window creates a prevailing air movement inside the room but not the velocity. The temperature inside the room was spread evenly. But the air velocity was achieved lower than the use of the awning.

From the simulation result that showed in Table 2 three alternatives created higher velocity than the existing building inside the room:
- High velocity in R1 : alternative $\mathrm{I} 3$

$$
\mathrm{VR} 1=0.25 \mathrm{~m} / \mathrm{s} \quad \mathrm{VR} 2=0.05 \mathrm{~m} / \mathrm{s}
$$

- High velocity in R2 : alternative A1

$$
\mathrm{VR} 1=0.14 \mathrm{~m} / \mathrm{s} \quad \mathrm{VR} 2=0.19 \mathrm{~m} / \mathrm{s}
$$

- Almost the same velocity in both room:

alternative D1

$$
\mathrm{VR} 1=0.19 \mathrm{~m} / \mathrm{s} \quad \mathrm{VR} 2=0.18 \mathrm{~m} / \mathrm{s}
$$

Because the target in this study is to optimize the air velocity in the building, thus the alternative D1 was chosen as the best alternative because it could create almost the same velocity in the booth room.

This alternative was observed again at a certain time regarding the common time study for thermal comfort (Apritasari, 2004). There were four-time that were chosen to observe the design: $10.00 \mathrm{am}, 12.00 \mathrm{pm}, 2.00$ pm, and $4.00 \mathrm{pm}$.

Table 3: simulation result for air velocity in certain investigation time

\begin{tabular}{|l|l|l|l|l|}
\hline & $10.00 \mathrm{am}$ & $12.00 \mathrm{pm}$ & $2.00 \mathrm{pm}$ & $4.00 \mathrm{pm}$ \\
\hline $\mathrm{R} 1(\mathrm{~m} / \mathrm{s})$ & 0.3 & 0.19 & 0.27 & 0.43 \\
\hline $\mathrm{R} 2(\mathrm{~m} / \mathrm{s})$ & 0.3 & 0.18 & 0.27 & 0.4 \\
\hline
\end{tabular}

It found that the design resulted in inconsistent results throughout different conditions (difference temperature and outdoor air velocity). The result proved that the air velocity between R1 and R2 was still near.

In addition to the position of the air that entered the building which was perpendicular to the windward side. There was another observation scenario that carried on. There are parallel directions and diagonal directions ( $45^{0}$ to the windward side). The observation point was taking on the middle area of the room.

Table 4: simulation result for the different direction of the incoming wind

\begin{tabular}{|l|l|l|}
\hline & Parallel & $45^{0}$ \\
\hline R1(m/s) & 0.19 & 0.03 \\
\hline R2(m/s) & 0.15 & 0.15 \\
\hline
\end{tabular}


In Table 4, it can be seen that the result is not a significant difference in the parallel direction of the incoming wind. But, the direction of $45^{\circ}$ incoming winds resulted in different air velocity in $\mathrm{R} 1$ and $\mathrm{R} 2$. It can be caused by the position of the room. R2 could receive more wind and this room position could reduce the incoming wind that passed into R1. Thus, the air velocity in R1 was lower than R2.

\section{Conclusion}

The simulation showed that the use of awning windows with the position from floor level $0.35 \mathrm{~m}$ in $\mathrm{R} 1$ and $0.55 \mathrm{~m}$ in $\mathrm{R} 2$ resulted in optimizing air velocity in both the investigation room (R1 and R2). These alternatives also showed a consistent result while tested in several conditions (certain time: difference temperature and outdoor air velocity, and difference air direction). Thus, the use of these alternatives was proposed to be used in residential buildings to create proper cross ventilation in buildings. Besides the covid 19 condition that requires good air circulation in the building, will prevent the virus from spreading in a building.

\section{References}

Apritasari, Y. D. (2004). Optimize the Percentage of Opening Area due to Thermal Comfort in Hot Humid Residential (Using Eco House as Model Simulation). The 5th International Seminar On Sustainable Environmental Architecture.

Bagdasarian, N., Mathews, I., Ng, A. J. Y., Liu, E. H., Sin, C., Mahadevan, M., \& Fisher, D. A. (2020). A safe and efficient, naturally ventilated structure for COVID19 surge capacity in Singapore. Infection Control \& Hospital Epidemiology, 1-3. Cambridge Core. https://doi.org/10.1017/ice.2020.309

Bhagat, R. K., Davies Wykes, M. S., Dalziel, S. B., \& Linden, P. F. (2020). Effects of ventilation on the indoor spread of COVID-19. Journal of Fluid Mechanics, 903, F1. Cambridge Core. https://doi.org/10.1017/jfm.2020.720

Cahyani, S. D. (2018). Simulasi Perilaku Aliran Udara Melalui Model Pengujian Stack Effect pada Bangunan Menengah Berselubung Ganda di Tropis Lembab. Jurnal Lingkungan Binaan Indonesia, $6(1)$.

Guo, W., Liu, X., \& Yuan, X. (2015). Study on Natural Ventilation Design Optimization Based on CFD Simulation for Green Buildings. 9th International Symposium on Heating, Ventilation and Air Conditioning (ISHVAC) and the 3rd International Conference on Building Energy and Environment (COBEE.

Kindangen, J. L. (2003). Pengaruh tipe jendela terhadap pola aliran udara dalam ruang. Jurnal Dimensi, 31.

Lechner, N. (2007). Heating, Cooling, Lighting Metode Desain Untuk Arsitektur. PT Raja Grafindo Persada.

Liedtke, S. (2020). Proper ventilation is a key tool to prevent the spread of Covid-19. https://www.youtube.com/watch?v=nNK 1ZV1A3ps\&feature=youtu.be

Lishman, B., \& WOODS, A. W. (2006). The control of naturally ventilated buildings subject to wind and buoyancy. Journal of Fluid Mechanics, 557, 451-471. Cambridge Core. https://doi.org/10.1017/S0022112006009 931

Passivent Limited. (2015). Natural Ventilation Strategies for Commercial Buildings. Passivent, 1-7.

WHO. (2020). Coronavirus disease (COVID19): Ventilation and air conditioning in public spaces and buildings. WHO.

Yang, T., \& Clements-Croome, D. (2012). Natural Ventilation in Built Environment (pp. 6865-6896). https://doi.org/10.1007/978-1-44190851-3_488 